This is the peer reviewed version of the following article: Koczberski, Gina and Curry, George N. and Bue, Veronica. 2012. Oil palm, food security and adaptation among smallholder households in Papua New Guinea. Asia Pacific Viewpoint. 53 (3): pp. 288-299, which has been published in final form at http://dx.doi.org/10.1111/j.1467-8373.2012.01491.x. This article may be used for non-commercial purposes in accordance with Wiley Terms and Conditions for Self-Archiving at http://olabout.wiley.com/WileyCDA/Section/id-820227.html\#terms 


\title{
Oil palm, food security and adaptation among smallholder households in Papua New Guinea
}

\author{
Gina Koczberski, George N. Curry and Veronica Bue
}

School of Social Sciences and Asian Languages, Curtin University, GPO Box U1987, Perth, WA 6857, Australia.

Email: g.koczberski@curtin.edu.au (G. Koczberski); g.curry@curtin.edu.au (G.N. Curry); vgawibue@gmail.com (V.Bue)

The reference for this article is:

Koczberski, G., Curry, G.N. and Bue, V. (2012). Oil palm, food security and adaptation among smallholder households in Papua New Guinea. Asia Pacific Viewpoint 53(3), 288-299.

Please note that there may be some minor differences between this PDF version of the paper and the published article. Reprints of this article can be obtained from Gina Koczberski < g.koczberski“at"curtin.edu.au>

\begin{abstract}
This paper is concerned with food security and access to land for food crop gardening among first and second generation migrant oil palm producers in West New Britain Province, Papua New Guinea. We examine changes in food security due to the rapid population growth in the presence of growing demand for land for oil palm production. Despite oil palm providing the major source of income for most migrant households, food crop gardening remains a primary livelihood activity, particularly for women, and especially so, during periods of low oil palm prices. Rising population and land pressures pose a threat to household food security and have implications for the supply of food to the rapidly growing urban population in the province. The paper begins by describing how household food security and access to land have changed over the past two decades. Then the paper examines how smallholder households are responding to shortages of garden land through the intensification of land use, intercropping immature oil palm with food crops and seeking access to land beyond the oil palm block. The paper also considers the role that research, agricultural extension and the milling companies can play in supporting strategies to promote food security among smallholders.
\end{abstract}

Keywords: food security, land intensification, land use pressure, Papua New Guinea, smallholder oil palm

\section{Introduction}

Oil palm production has grown rapidly in Papua New Guinea (PNG) over the past 20 years, and it is now the largest agricultural export earner. Currently, over 136000 hectares are planted to oil palm in five provinces: West New Britain, Oro, Milne Bay, New Ireland and Morobe (Fig. 1). All oil palm-growing areas operate, to some extent, on a nucleus estate smallholder model, whereby smallholders supply oil palm fruit to mills operated by the nucleus estate company. Around 33\% of PNG's palm oil is produced by smallholders, mostly in West New Britain Province (WNBP).

This paper investigates how migrant oil palm smallholders in WNBP maintain household food security in the context of growing demand for land for oil palm production and rapid population growth. Household food security in PNG is currently considered to be high with around $83 \%$ of the population living in rural areas where subsistence agriculture is the 
primary economic and social activity (Bourke, 2000). Most of the rural population has adequate access to gardening land sufficient to meet their minimum daily calorie requirements, although protein-energy malnutrition exists in some rural districts as a result of insufficient access to high protein and energy-dense foods (e.g. oils and fats) and because of seasonal and short-term food shortages (Bourke, 2000: 6-7). Despite rapid population growth in PNG of around $2.3 \%$ per annum since $1966,83 \%$ of food energy and $76 \%$ of protein consumed in PNG continues to come from locally grown foods, derived largely from village gardens (Gibson, 2000; Bourke et al., 2009). These achievements reflect the continued importance of traditional social and trading relationships, the introduction of high yielding and rapidly maturing varieties of food crops, the relatively good access to customary land for most rural villagers, and their ability and willingness to innovate, alter agricultural techniques and adopt new crops (see, for example, Bourke, 2001; Banabas, 2011).

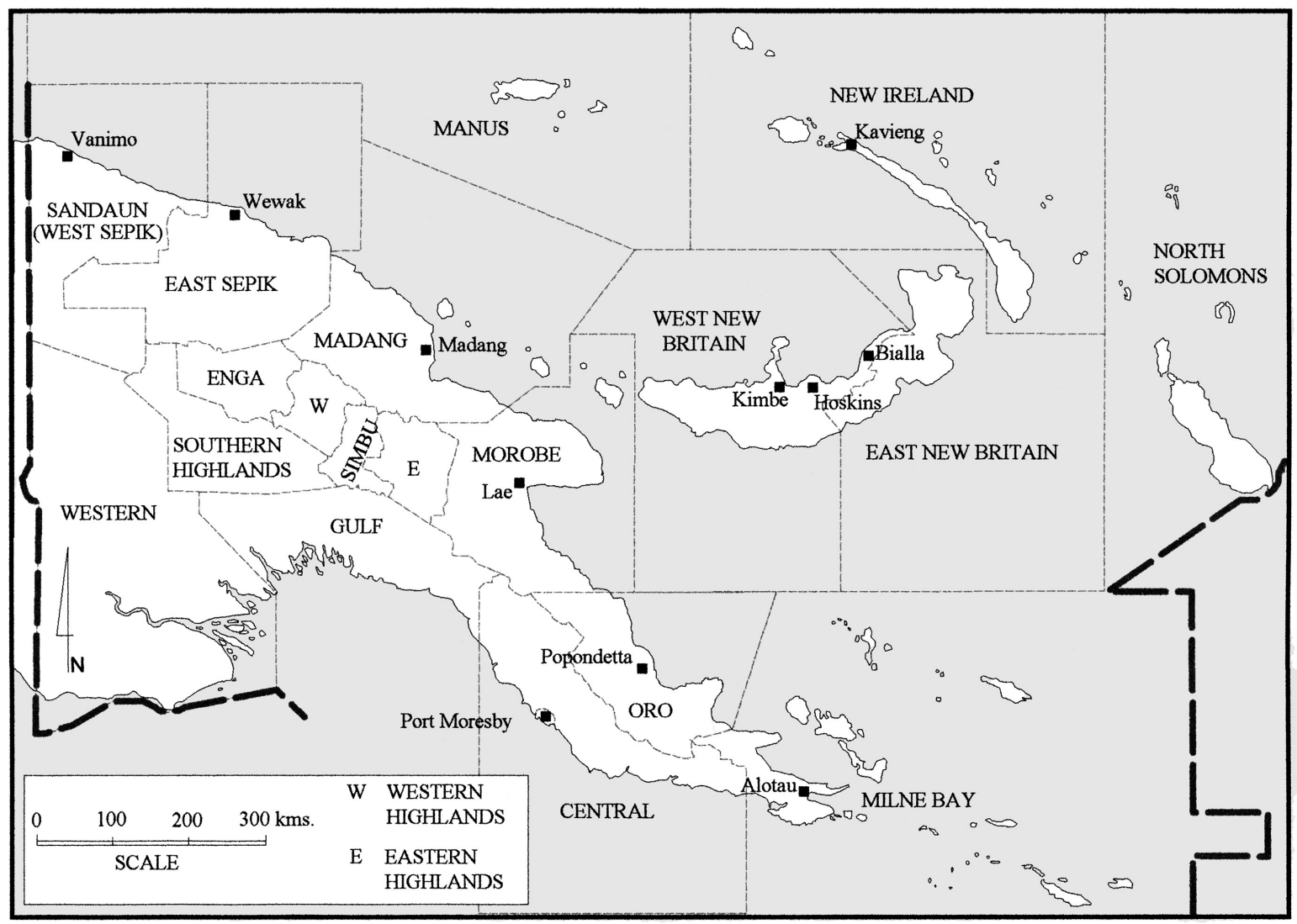

Figure 1. Location map of West New Britain Province

However, there are growing pockets of vulnerable households in urban and non-village rural areas. These groups have limited and/or insecure access to land and income, and together with truncated social and kinship networks struggle to maintain access to sufficient nutritious foods to meet their daily dietary needs. The increasing number of people moving from areas of disadvantage (mostly poorly serviced rural areas) to urban centres and rural regions where employment opportunities and services are better (Keig, 2001; Storey, 2006) is leading to a growing group of migrants who do not have customary rights to land for food gardening and who therefore depend on purchased food. Their vulnerability to food insecurity has been exacerbated by recent sharp increases in the prices of imported foods (McGregor and Bourke, 2009). 
A key question requiring investigation in PNG is how do migrant groups living in urban and non-village rural areas with limited and/or insecure access to land maintain household food and income security? In addressing this question, the paper focuses on first and second generation migrant oil palm farmers in WNBP. Settlers began growing oil palm in WNBP in the 1970s following the development of an oil palm land settlement scheme (LSS) at Hoskins. Over 3500 settler families were voluntarily recruited from other provinces of PNG and were granted individual state agricultural leases over blocks of 6.0-6.5 ha (Hulme, 1984). The paper begins by describing how household food security and access to land for food gardening on the LSS have changed over the past three decades. Then it examines how migrant households are responding and adapting to the loss of gardening land. The final section discusses the implications of the research findings and the role that industry can play in supporting strategies to promote food security among the migrant community of smallholders.

\section{Migration, land and garden food production}

PNG, like other developing countries in the 1960s, adopted land settlement programmes to promote agricultural and economic development. As instruments of national development, these LSSs were thought to have transformative powers. The Australian administration envisaged that by taking people out of the sociocultural context of village life and settling them on individualised land holdings on various settlement schemes, the perceived problems of traditional communal land tenure in constraining agricultural development would be overcome (Hulme, 1984). It was thought that Papua New Guineans would quickly recognise the benefits of an individualised land tenure system, a recognition that would hasten the replacement of customary land tenure based on group ownership with individual land titles. Furthermore, it was envisaged that as settlers became increasingly integrated into cash crop production, they would gradually reduce their dependence on subsistence production to become more market-oriented and market-driven producers and consumers. In this vision, settlers, through their experiences on their own land, would come to realise the benefits of breaking with their traditions and lifestyles so that subsistence agriculture would give way to cash crop production (for export) and an individualised system of land tenure would displace indigenous forms of land tenure.

Forty years since the establishment of the Hoskins LSS, the disappearance of indigenous social and economic systems and subsistence agriculture, which were considered necessary for progress and development to occur, has not eventuated. Despite a lifestyle well embedded in the market economy of producing oil palm, virtually all smallholders maintain food gardens, both for household consumption and cash income. Many smallholders spend considerably more time in food production than they do in oil palm-related work. For women in particular, gardening is a central component of their everyday lives. In 2000, when oil palm prices were relatively low, women at Kavui LSS subdivision allocated almost 2.5 times as much of their labour to food gardening as to oil palm, whereas, for men, gardening and oil palm were of about equal importance in terms of the time allocated to each activity (Koczberski et al., 2001). Despite much higher oil palm prices prevailing in 2010, food gardening remained a significant daily activity for most households and especially for women (Table 1). 
Table 1. Average proportions of time allocated to food gardening and oil palm work over a six-day period at Kapore subdivision in $2010(n=36)$

\begin{tabular}{|l|l|l|}
\hline Activity & Gardening (\%) & Oil palm (\%) \\
\hline Male blockholder & 35 & 65 \\
\hline Spouse & 76 & 24 \\
\hline
\end{tabular}

The principal food crops cultivated in smallholder gardens include banana (Musa various cultivars), Chinese taro (Xanthosoma sagittifolium), cassava (Manihot esculenta), sweet potato (Ipomoea batatas), yams (Dioscorea esculenta), corn (Zea mays) and an assortment of other vegetables including beans (Phaseolus vulgaris and Vigna unguiculata), capsicum (Capsicum annuum), pitpit (Saccharum edule), tomato (Lycopersicon esculentum) and greenleaf vegetables (e.g. aibika (Abelmoschus manihot), aupa (Amaranthus tricolor), Chinese cabbage (Brassica rapa cv.) and pak choi (Brassica rapa cv)). Peanuts (Arachis hypogaea) and tobacco (Nicotiana tabacum) are also popular cash crops that are grown and marketed locally. Although garden practices and food crop varieties have changed over time, some smallholders from particular ethnic groups continue to favour production of root crops from their home areas, even though they are second generation settlers.

Local marketing of garden foods provides women with an additional income source to oil palm. Food crops for local marketing are cultivated alongside those for household consumption, and it is common for smallholders to establish additional gardens of high-value crops such as peanuts, sweet potato and tobacco (Curry et al., 2012: 174). Fruits such as pineapples (Ananas comosus), pawpaw (Carica papaya), watermelon (Citrullus lanatus), banana (Musa cvs.) and betel nut (Areca catechu) are also grown for sale at local markets. Income from local marketing of garden foods is especially important for smallholders living on highly populated blocks and during periods of low oil palm prices.

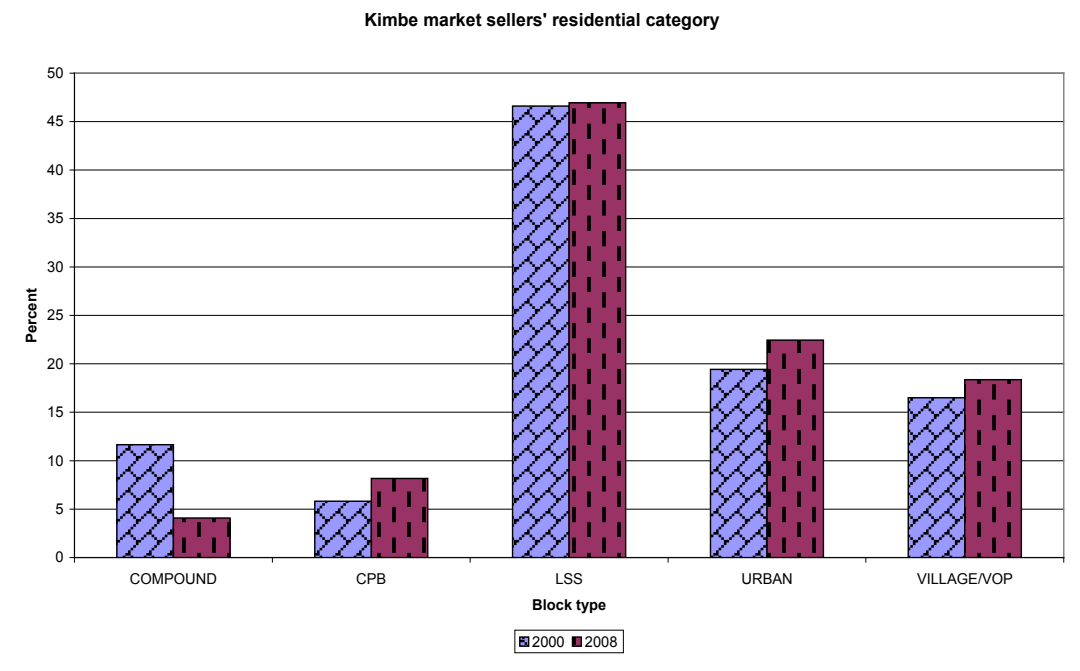

Figure 2. Kimbe market sellers' residential category for 2000 and 2008 (compounds are residential areas for company staff; CPB are two-hectare oil palm stands on land 'purchased' from customary landowners). CPB, Customary Purchase Blocks. Sources: Koczberski et al. (2001); Ryan (2009). 
For most women, local marketing of garden foods is their most important income source after oil palm. In surveys of local fresh produce markets in 2000 and 2008, women from the LSSs comprised one of the major groups selling produce at the main town market in Kimbe (Fig. 2). Although not shown in Figure 2, $78 \%$ and $70 \%$ of the root crops and vegetables on sale in 2000 and 2008, respectively, were from the LSS (Ryan, 2009: 53). Similarly, surveys conducted at six local markets in and around the LSSs and the main town of Kimbe in 2000 revealed that $54 \%$ of sellers were from the LSS, and they dominated sales of garden produce both in terms of monetary value and in their proportional share of the quantities of these items on sale (Koczberski and Curry, 2005; see Fig. 3 below). A follow-up survey in 2008 found that the proportion of market sellers from LSS blocks had decreased to $22 \%$ of the total number of sellers (Ryan, 2009). Ryan attributed the decline to the high oil palm prices (PGK200-220/tonne) prevailing at the time of his survey. Smallholders were placing more emphasis on oil palm production to take advantage of the higher prices. Yet despite this decline in the number of women from the LSS selling food, they remained the dominant group of sellers at Kimbe market (approximately $47 \%$ of all sellers) and continued to dominate sales of root crops and other vegetables (Ryan, 2009). Thus, food crops cultivated by LSS women play an important role in contributing to food security for the rapidly growing urban and peri-urban population of Kimbe.

By maintaining food gardens, smallholders reduce their vulnerability to fluctuating oil palm prices. The importance of gardening for food security was apparent in 24-hour-recall dietary surveys conducted with smallholders on the Hoskins LSS between September and November 2000 during a period of depressed oil palm prices (farm-gate price for fruit was PGK50/ tonne, $\mathrm{PGK} 1=$ AUD 0.66) and in May 2010 when oil palm prices were relatively high (farmgate price for fruit was PGK265/tonne, PGK1 = AUD0.41). Table 2 shows the proportions of meals consisting entirely of garden foods and meals containing at least one nongarden ingredient for the 2000 and 2010 dietary surveys. In 2000, 77\% of all meals consisted entirely of ingredients from food gardens. Nongarden ingredients of remaining meals consisted largely of store-purchased foods such as tinned fish, meat and rice. The store food component of meals tended to be concentrated within the first few days of receiving the monthly oil palm payment. In 2010, smallholders were relying less on food gardens in their daily diets with $43 \%$ of meals consisting entirely of ingredients from their food gardens (mainly root crops, green vegetables and bananas). The greater proportion of meals containing at least one store-purchased ingredient can be explained by the relatively high oil palm prices at the time of the surveys. Smallholders generally continue to rely heavily on food garden production for daily food intake, and this is especially so during periods of depressed oil palm prices when food gardens are an important buffer against declining household incomes. When oil palm prices are high, smallholders reduce their consumption of garden foods and consume more purchased store foods that are considered more prestigious than garden foods in most of PNG. 


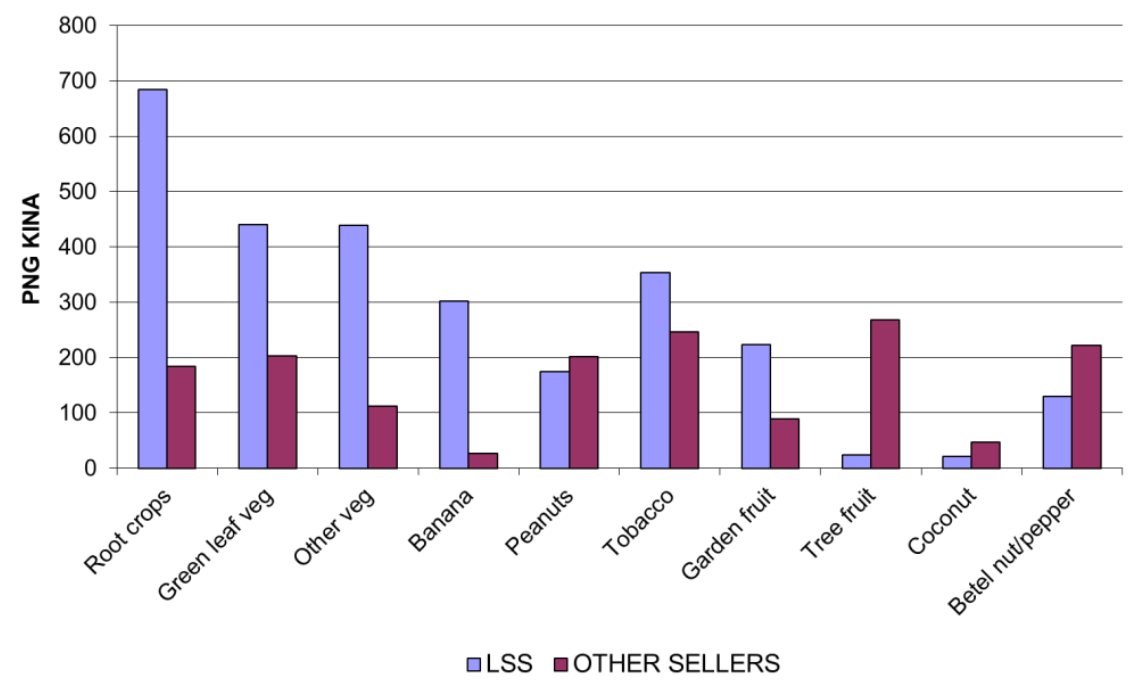

Figure 3. Values of categories of garden items at local markets in Hoskins-Kimbe area (Koczberski and Curry, 2005: 332). LSS, land settlement scheme; PNG, Papua New Guinea.

Table 2. Sources of all meal ingredients categorised by garden and non-garden food items

\begin{tabular}{|l|c|c|}
\hline Year & $\begin{array}{c}\text { Percentage of meals consisting } \\
\text { entirely of garden foods }\end{array}$ & $\begin{array}{c}\text { Percentage of meals } \\
\text { containing at least one non- } \\
\text { garden item }\end{array}$ \\
\hline 2000 & $77 \%$ & $23 \%$ \\
\hline 2010 & $43 \%$ & $57 \%$ \\
\hline
\end{tabular}

(Sources: Koczberski et al., 2001; Bue unpublished data, 2010)

\section{Changing status of food security and smallholder responses}

When the LSSs were first established, a six hectare block was considered sufficient for the needs of a single nuclear family. A lease condition was that four hectares of oil palm would be planted within two years of settling on the block. The remaining two hectares were viewed as 'reserve land' for food gardens, and settlers were expected to be self-sufficient in food from their own gardens shortly after moving onto their blocks (Landell Mills Ltd., 1991). The two hectare reserve land was used by smallholders for food gardens until the early 1990s, when settlers began planting an additional two hectares of oil palm making six hectares in total (Curry et al., 2007; Dewhurst, 2007). Over 90\% of blocks at Hoskins now have six hectares of oil palm, and Ryan (2009: 48) reported that 83\% of LSS women selling food at local markets claimed their blocks were fully planted to oil palm. The extension of oil palm plantings into the 'reserve land' is explained predominantly by the significant population growth on the LSS since the schemes' establishment and the need to increase income to meet the cash demands of a larger resident population. Population density on the Hoskins LSS has more than doubled from 7.24 persons per block in 1975 (Benjamin, 1977) to 14.72 in 2010. The original single household block has been replaced by multiple household blocks where sons (and sometimes daughters) marry and raise their own children on the block. Now several households rely on a diminishing area of land on the block for food gardening. The trend to establish these additional areas of oil palm in the food garden reserve area has been encouraged further by high oil palm prices since 2007. Smallholders also claim that declining soil fertility of the two hectare reserve land was another factor influencing their decision to expand their oil palm holdings to six hectares. ${ }^{1}$ It is possible that the more intensive labour 
demands for gardening in the reserve land may have influenced decisions to convert the reserve area to oil palm.

Table 3. Changes in food gardening systems from 1975 to 2010

\begin{tabular}{|c|c|c|}
\hline 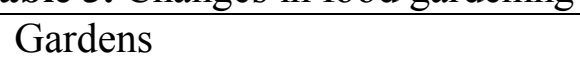 & $1975^{1}$ & $2010^{2}$ \\
\hline Size of leasehold block & 6.07 & 6.07 \\
\hline Persons per block & 7.24 & 14.72 \\
\hline $\begin{array}{l}\text { Area of leasehold block planted } \\
\text { to oil palm }\end{array}$ & $3.24 \mathrm{ha}$ & 6.00 \\
\hline $\begin{array}{l}\text { Garden land available on block } \\
\text { per year (i.e. land not planted to } \\
\text { oil palm) }\end{array}$ & 2.83 & 0.61 \\
\hline $\begin{array}{l}\text { Mean garden area cropped per } \\
\text { head }\end{array}$ & 0.058 & 0.0405 \\
\hline $\begin{array}{l}\text { Required cultivated garden area } \\
\text { per block to meet needs of } \\
\text { resident population }\end{array}$ & 0.402 ha & $0.5964(0.6)$ \\
\hline Fallow period & $6-9$ years & $\begin{array}{l}\text { Assumes } \\
\text { permanent cultivation }\end{array}$ \\
\hline $\begin{array}{l}\text { Intercropping of immature oil } \\
\text { palm with food crops }\end{array}$ & Non-existent & $\begin{array}{l}35 \% \text { of the total area of } \\
\text { food gardens }\end{array}$ \\
\hline
\end{tabular}

Given that most blocks are now fully planted to oil palm but virtually all smallholders continue to maintain food gardens, it is important to understand the various ways smallholders are adapting to the short- and long-term pressures in their environment. Our results indicate that smallholders are responding to shortages of garden land through the intensification of land use, intercropping immature oil palm with food crops and seeking access to land beyond the LSS block. Each strategy is discussed below with a view to gauging the long-term sustainability of the farming systems on the LSSs.

\section{Intensification of food production}

As the per capita land area on the LSS for food crop gardening has contracted through time due to population growth and the conversion of the two hectares of reserve land to oil palm (Table 3), intensification of land use has occurred. Land use pressure has led to shorter fallow periods, extended cultivation periods, greater reliance on short-maturing food crops that are more tolerant of less fertile soils and the increased use of fertilisers and pesticides.

In 1975 when population densities were much lower and just over half of the six-hectare leasehold block was planted to oil palm, almost three hectares per block were available for food gardening, which was more than sufficient to meet the average needs for garden area per block of 0.4 ha (Table 3). Gardens were cultivated for 12-18 months, with a fallow period of 6-9 years, which allowed seven years without crops before returning to the original plot (Benjamin, 1977). In 2010, mean garden area required per block had risen to 0.6 ha, whereas the effective area of gardening land had contracted to a mean of 0.6 ha per block across the LSS as smallholders converted the two hectares of 'reserve land' to oil palm. ${ }^{2}$ Hence, there is now barely adequate land for food gardening, with virtually no scope for fallowing. Over the 
same period, through intensification, smallholders have reduced the mean garden area cropped per head from 0.06 to 0.04 ha (Table 3 ), ${ }^{3}$ and many have begun utilising land during the oil palm replanting stage to intercrop immature palms with food crops (see below).

Smallholders have also maintained food production by favouring staple food crop types that are more tolerant of poorer soils, quick maturing and less prone to pest attack. Compared with Benjamin's 1975 data, smallholders were planting fewer yams and taro, and relying more on bananas and cassava - crops that are higher yielding and can tolerate less fertile soils (Table 4). Yams, for example, require fertile soil and are typically grown as a first crop in new gardens cleared from grass or shrub fallows.

Table 4. Average area per block planted to different food crops in 1975 and 2010 (ha)

\begin{tabular}{|l|l|l|}
\hline Crop & \multicolumn{1}{|c|}{$\begin{array}{c}1975 \\
\text { Average area per block } \\
\text { (ha) }\end{array}$} & $\begin{array}{l}\text { 2010 } \\
\text { Average area per block } \\
\text { (ha) }\end{array}$ \\
\hline Sweet potato (Ipomoea batatas) & 0.123 & 0.079 \\
\hline Peanuts (Arachis hypogaea) & 0.055 & 0.037 \\
\hline $\begin{array}{l}\text { Chinese taro } \\
\text { (Xanthosoma sagittifolium) }\end{array}$ & 0.086 & 0.081 \\
\hline Taro (Colocasia esculenta) & 0.060 & 0.037 \\
\hline Yams (Dioscorea cvs) & 0.048 & Insignificant \\
\hline Cassava (Manihot esculenta) & Insignificant plantings & $\begin{array}{l}\text { Planted as boundary } \\
\text { crop }\end{array}$ \\
\hline Bananas (Musa cvs) & $\begin{array}{l}\text { No figure* } \\
\text { (insignificant plantings) }\end{array}$ & 0.203 \\
\hline Totals & 0.372 & 0.437 \\
\hline Benjamin (1977) did not mention bananas throughout her report, except to note that smallholders from East New Britain had the lowest \\
\hline
\end{tabular}
average garden area because they grew a lot of bananas around their house sites.

Table 5. Proportion of gardens where pesticide was applied by dominant crop $(n=239)$

\begin{tabular}{|l|c|c|}
\hline Dominant crop in garden & No. of gardens & $\begin{array}{c}\text { Applied } \\
\text { pesticide (\%) }\end{array}$ \\
\hline Aibika (Abelmoschus manihot) & 21 & 81 \\
\hline Cabbage varieties (Brassica cvs) & 7 & 100 \\
\hline Banana (Musa cvs) & 43 & 23 \\
\hline Peanut (Arachis hypogaea) & 42 & 14 \\
\hline Pineapple (Ananas comosus) & 4 & 0 \\
\hline Chinese taro (Xanthosoma Sagittifolium) & 36 & 19 \\
\hline Taro (Colocasia esculenta) & 65 & 61 \\
\hline Sweet potato (Ipomoea batatas) & 8 & 50 \\
\hline $\begin{array}{l}\text { Other: Snake Bean (Vigna unguiculata cv. group } \\
\text { Sesquipedalis); Ginger (Zingiber officinale); } \\
\text { Tobacco (Nicotiana tabacum) }\end{array}$ & & \\
\hline All & 239 & 27 \\
\hline
\end{tabular}

Similarly, taro is prone to pest attack when planted in secondary gardens with lengthy cultivation cycles. In 1975, cassava was a minor food crop (C. Benjamin, pers. comm., 18 May 2012), but by 2010 it was commonly planted as a boundary crop. Smallholders were also adopting quick-maturing food crop varieties and these were becoming more common in 
the suite of food crops cultivated. For example, wan mun kaukau (I. batatas), which matures in less than three months, was displacing older varieties of sweet potato that take four or five months to mature. Similarly, the dominant banana grown by smallholders was kiaukiau, a triploid banana that takes less time to mature than other banana varieties.

Intensification of food production was also reflected in increased use of fertilisers and pesticides. No growers were identified using fertiliser on their food gardens in 2000. In 2010, interviews with smallholders and some extension officers indicated many smallholders were applying oil palm fertiliser to their food gardens. Similarly, pesticide use in food gardens was not observed in past surveys. However, by 2010, pesticides were applied in $29 \%$ of 239 gardens surveyed (Table 5). Pesticide application was not restricted to green-leaf vegetables as is commonly assumed in PNG; pesticides were being applied to a diverse range of food crops both for sale and home consumption, though there was a tendency for greater use of pesticides on crops intended for local sale (Table 5). It is likely that increased pesticide use was due to reduced fallow periods, extended cultivation periods and a trend towards monoculture production of food crops, all trends likely to be conducive to pest outbreaks.

\section{Gardening in new locations}

With the reduction of garden 'reserve land' on LSS blocks, settlers have responded by cultivating gardens in new locations on and off the block. Garden surveys on two of the earliest LSS subdivisions established at Hoskins and Bialla revealed that while almost a quarter of the total cultivated garden area was at the rear of the block on land remaining after planting six hectares of oil palm, smallholders were bringing small patches of land previously considered unsuitable for food gardens into production. These included hilly sections of the block unsuitable for oil palm and land around house sites. Also, some smallholders were not replanting the full number of palms after poisoning senile palms and were leaving out an edge row of palms to make more land available for food gardening. Gardens cultivated on this 'converted land' accounted for just over $10 \%$ of the total area of smallholder food gardens (Fig. 4).

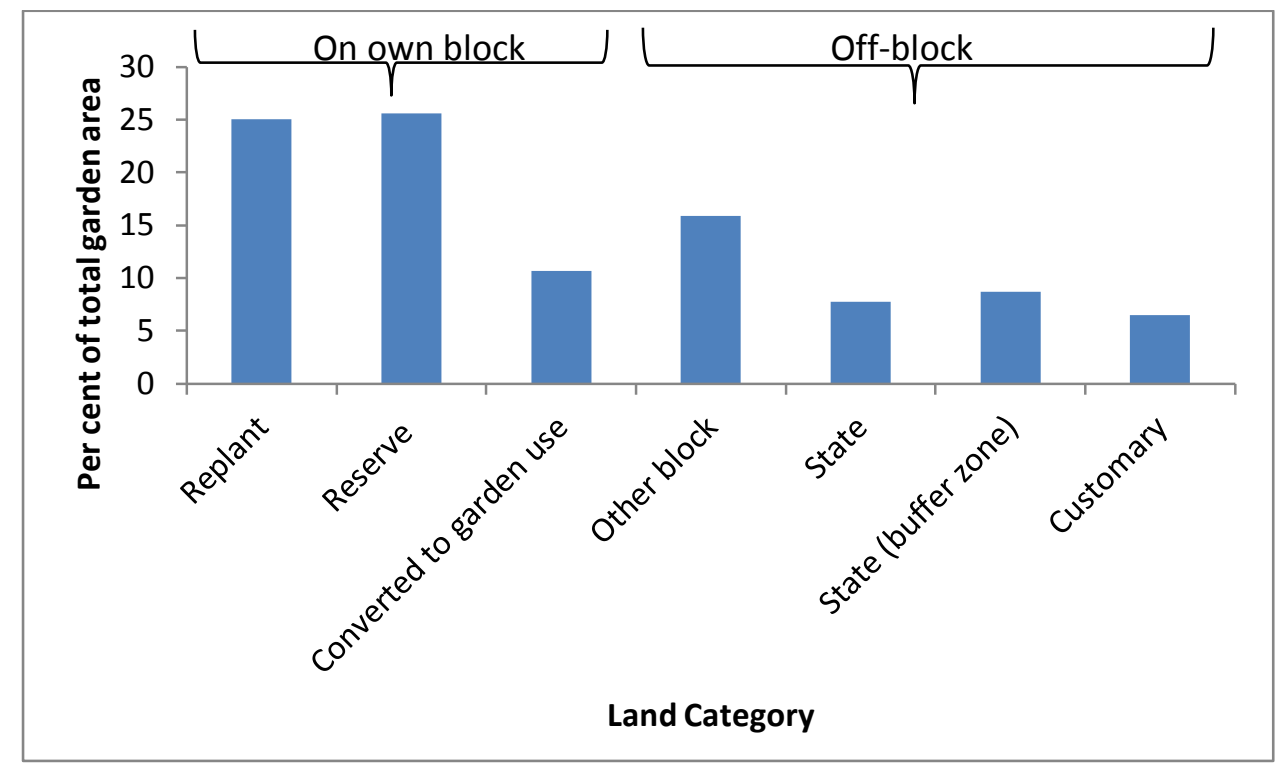

Figure 4. Proportions of garden area located on different land types and tenures 
One relatively new and widely adopted gardening innovation has been the intercropping of immature oil palm with food crops where senile oil palm stands had been poisoned and replanted (Fig. 4). Immature oil palm can be intercropped with food crops for two years until the oil palm canopy closes. Smallholders practice rotational replanting of two-hectare stands of oil palm every 22 years, which means two hectares are available for food gardening for 6 of every 22-year cultivation round on a block with six hectares of oil palm. Thirty-five per cent of the total area of food gardens was in replant sections, either on smallholders' own blocks $(25 \%)$ or in the replant sections belonging to other growers, usually a relative $(10 \%)$. Interviews with smallholders and extension officers revealed that, while a few smallholders were using the replant sections of their own leasehold blocks as long as 20 years ago when the first round of oil palm replanting took place, their main gardening area remained the twohectare 'reserve land' on their blocks. Presently, the replant section provides the only substantial area for food gardening on a smallholder block (Fig. 4) and appears to be used considerably more intensively than in the past. In nearby villages where there are no land shortages, food gardens are rarely established in newly planted oil palm stands.

Usually peanut or other crops intended for sale such as cabbage varieties (Brassica spp), beans, cucumber and taro are planted as first crops in immature stands of oil palm. Typically, sweet potato is the second crop in rotation with peanut and in some cases peanut is replanted as a third crop. The replant section is usually divided into small plots of food crops for home consumption and for sale at local markets. Crops intended for sale at local markets such as peanut, cucumber and cabbage varieties tend to be cultivated as single species plantings, whereas those for home consumption tend to follow the traditional pattern of a polyculture of mixed cropping.

When there was insufficient land for food gardens on their own blocks, smallholders sought the assistance of friends and relatives living on nearby blocks for access to gardening land: $16 \%$ of the total garden area was located on other blocks, which indicated the growing importance of social networks for accessing land. Smallholders were also cultivating food gardens illegally on state land surrounding the LSS, some of which was categorised as 'buffer zone' land in environmentally sensitive areas along creek lines (Fig. 4). Although there is some evidence that smallholders were using state land surrounding the LSS for gardening as early as the mid-1980s (Benjamin and Wapi, 1982), the area cleared for gardening has expanded greatly over the past 10-15 years as population and land pressures on the LSS continued to build.

Some smallholders have made informal arrangements with neighbouring customary landowners for access to gardening land: $9 \%$ of the total garden area was located on customary land (Fig. 4). Typically, these agreements are for the cultivation of food crops for household consumption only and not for the production of food crops intended for sale at local markets. It is common for the cultivators to give occasional gifts of food and/or small amounts of cash to the customary landowners as a means of maintaining informal access rights to the land of their hosts (Koczberski et al., 2009).

Thus, as the land available for food gardening on the block contracts, smallholders are becoming more dependent on off-block access to gardening land with almost $40 \%$ of the total garden area now being off-block (Fig. 4). For women, who undertake most of the gardening tasks, more distant gardens means more time spent travelling to and from gardens. Also, for gardens located on state or customary land, tenure security was lacking, and the theft of food crops was common. 


\section{Land acquisition strategies}

Some second generation settlers have been acquiring two-hectare blocks of customary land for the cultivation of oil palm. These informal agreements with members of customary landowning groups in nearby villages also provide access to land for food gardening and residence. Over 3000 ha of customary land in the Hoskins area have been 'sold' to people from outside the customary landowning group. Although it was not known how many of these blocks have been established by former residents of the LSS, it is likely that a significant proportion of them are occupied by second generation settlers of the LSS. These blocks on customary land are effectively satellites of the LSS block, enabling families to relieve land pressures on the LSS by moving some residents while expanding oil palm production and the land available for food gardening (Koczberski et al., 2012). When some LSS residents move on to customary land, per capita income rises on the LSS block as a larger proportion of garden produce is diverted to local markets rather than consumed, and oil palm income is shared among fewer families (Koczberski and Curry, 2005).

Most land 'sales' to settlers rarely involve formal procedures and typically there is little documentary evidence of the land transaction, nor any written record of the agreed purchase price, or size and boundary of the land parcel (Curry and Koczberski, 2009). Establishing gardens and other forms of livelihood support on another's customary land in PNG poses risks for settlers because the legitimacy of their tenure rights can be challenged by members of the customary landowning group. From the perspective of most customary landowners, land rights granted to settlers are never permanent and exclusive (Koczberski et al., 2009). That some second generation settlers are willing to pursue this high-risk strategy to access land is indicative of the land and demographic pressures on their blocks and the increasing longterm vulnerability of the settler population as they become more dependent on off-block resources such as land.

\section{Sustaining livelihoods and food security}

A fundamental challenge facing the LSSs over the next 10-15 years is whether existing farming systems will be able to meet the food and cash income requirements of the growing population in a sustainable manner. Critical to addressing the growing population and land pressures on the LSSs is the need to explore innovative ways to increase food output. For example, the introduction of new farm management techniques to improve yields of existing food crops combined with the introduction of new and improved crop varieties, livestock and aquaculture is crucial to developing productive and sustainable food systems. One strategy that is currently being trialled, and receiving support from the milling companies and agricultural extension services, is alternative planting arrangements for oil palm to extend the period of intercropping from two to about 10 years (Banabas, 2011). ${ }^{4}$ Reduced inter-palm distance and plots with wider avenues aligned east-west allow more light to penetrate to ground level, thereby greatly expanding the effective area of land available for diversified food crop production. In the current trial, the wider avenues are being planted with a range of high-yielding food crops and fuel-wood species for home consumption and sale at local markets. Although the trial has the potential to increase food self-reliance through improving the incorporation of both food and cash crops into the farming system, such a trial provides only breathing space as the population continues to grow.

In an ideal scenario, another option to improve food security would be to encourage smallholders to reduce the area under oil palm cultivation and revert to the four-hectare planting and bring the two-hectare plot back into food production. However, oil palm is a 
long-term investment and for most smallholders such initiatives are not easy to make, at least in the short term. It would also mean managing on much lower levels of cash income. In 2011, a smallholder producing at the average smallholder productivity level of 22 tonnes/ha would have earned PGK 7480/ha (USD 3106). Given that several households per oil palm block depend heavily on oil palm income for everyday needs, school fees and other household expenses, reducing the area of oil palm for food gardens is not a realistic option for most smallholders. Other options, such as converting oil palm to alternative cash crops, are constrained due to the lease conditions that stipulate the planting of oil palm. Despite this condition of the lease, there are no other commonly grown smallholder cash crops, such as cocoa or coconuts, that provide a return to land and labour as favourable as that from oil palm (Allen et al., 2009).

Perhaps the most viable long-term strategy is for increased income diversification, with less dependence on agriculture in the suite of livelihood activities pursued by LSS families. Income diversification, particularly off-farm income, has long been known to be associated with higher farm investment and innovation levels and greater risk-taking during innovation (e.g. Evans and Ngau, 1991; Koczberski and Curry, 2005). Farmers are more likely to hire labour, purchase farm inputs and acquire additional land, all of which contribute to raising production and incomes. On the LSSs in WNBP, income diversification is already occurring with the number of non-oil palm income sources increasing as mean block population rises (Koczberski and Curry, 2005: 330). It appears, therefore, that there is willingness and capacity among growers to diversify income sources and it would seem appropriate for the oil palm industry - companies and the extension agency - to facilitate such trends through training programmes to assist smallholders to establish small on-farm and off-farm business enterprises. Such businesses might include the repair of tools and wheelbarrows and other small-scale enterprises currently managed by the milling companies or extension agency, such as the sale and delivery of farm inputs. The cultivation of high-value crops like spices inter-planted with immature oil palm could also be promoted, especially if the wider avenue spacing trial in oil palm proves successful.

However, strategies to increase the functional supply of land for food gardening or to diversify incomes are ultimately constrained by continuing rapid population growth on the LSSs, which shows no sign of abating. The effects of population growth are exacerbated by the broader economic and political context of PNG. Unlike many Southeast Asian countries, there are few employment opportunities in PNG's urban industrial sector and although present mining developments in PNG are creating new economic and employment opportunities, many of these are in areas not easily available to smallholder farmers. Also, the growing intolerance of urban in-migration in nearly every urban centre in PNG, combined with a reluctance to accept returning second and third generation migrants in their 'home' villages, means that opportunities for settlers to move off-block are very limited, apart from insecure tenure on nearby customary land (Curry and Koczberski, 2009). Similarly, any functional increase in gardening land brought about by the adoption of new oil palm planting arrangements will be eroded in time by population growth. It remains to be seen whether migrant smallholders, given their capacity to adapt to difficult environmental circumstances, will convert new opportunities from livelihood diversification and enhanced access to gardening land into long-term sustainable gains by slowing population growth enough to initiate a demographic transition on the schemes. 


\section{Conclusion}

Garden food production, whether for domestic consumption or for sale at local markets, is a fundamental component of the livelihood strategies of the vast majority of oil palm smallholders living on the LSSs. Accordingly, the long-term viability of the smallholder sector depends to a considerable extent on the food and income security provided by access to gardening land. However, rising population and increasing land pressures on the LSSs can pose a threat to household food security. Although the study reveals that migrant smallholders are adapting to demographic and economic pressures through developing a range of coping strategies to maintain food security, it is also evident that some smallholders are adopting strategies that may ultimately increase their vulnerability to food insecurity and livelihood breakdown. Smallholders, for example, have possibly traded longterm food security for short-term income gains by expanding the area of oil palm production, thereby leaving themselves more vulnerable to the vagaries of world market prices for palm oil. They may have little choice but to intensify production of oil palm through greater investments of labour and other farm inputs. Thus, the old refuge in the subsistence economy during periods of low commodity prices is being undermined, whereas the benefits of cash income gains through production increases are being eroded steadily by population growth, thereby exacerbating the stresses in the cash and subsistence economies simultaneously. This suggests that the situation is becoming more difficult to manage through time as a result of rising demographic and land pressures. Hence, a major challenge for the long-term viability of the smallholder sector will be to address rising population and land pressures and develop a range of innovative interventions that assist in sustaining livelihoods and food security.

\section{Acknowledgements}

This paper is from collaborative research between Curtin University and the PNG Oil Palm Research Association with funding from the Australian Centre for International Agricultural Research. We are grateful for the cooperation and assistance of the Oil Palm Industry Corporation, especially Otto Pukam, Paul Kausa and Steven Oiza. The paper benefited from useful discussions with Dr Murom Banabas (PNGOPRA) and Cecelie Benjamin on smallholder farming practices in the 1970s. Thanks to the many smallholders who supported the study. The authors are also grateful to the reviewers for their very helpful feedback on the paper.

\section{Notes}

1 Several extension officers confirmed that some smallholders in the late 1990s had abandoned their two-hectare reserve land due to declining soil fertility.

2 Calculated on the basis that a block with six hectares of oil palm ( $3 ¥ 2 \mathrm{ha}=6 \mathrm{ha})$ using rotational planting will have two hectares of replant available for six years in a 22-year period $(6 / 22=0.2727 ¥ 2 \mathrm{ha}=0.54$ ha per year $+0.07 \mathrm{ha}=0.61$ ha garden land available per year).

3 If LSS residents were to plant gardens at the area per capita that Benjamin noted in 1975 ( 0.058 ha per person), total garden land demanded in 2010 would have been 0.85 ha.

4 This strategy emerged from a six-year trial from 2002 to assess different planting densities and spacing of oil palm in the plantation sector for use of vehicles for infield collection of harvested fruit. The increased vegetation cover thus reduced problems of soil compaction from the use of machines. Yield data from the trial have shown no yield penalty from shortened inter-palm distance with wider avenue plots. These findings for the plantation sector are of course of great significance to the smallholder sector because of the potential to extend the period that oil palm stands can be intercropped with food crops. 


\section{References}

Allen, M., R.M. Bourke and A. McGregor (2009) Fluctuations in village cash crop production, in R.M. Bourke and T. Harwood (eds), Food and agriculture in Papua New Guinea, pp. 411-419. Canberra: ANU Press.

Banabas, M. (2011) Intercropping food crops and oil palm in smallholder oil palm farming systems in Papua New Guinea, Presented at the symposium on 'Logging, Oil Palm and Livelihoods in Papua New Guinea' hosted by the Cairns Institute and the Centre for Tropical Environmental and Sustainability Science, James Cook University, Cairns, 20 April, 2011.

Benjamin, C. (1977) A survey of food gardens in the Hoskins oil palm scheme, Papua New Guinea Agricultural Journal 28(2-4): 57-71.

Benjamin, C. and I. Wapi (1982) Subsistence gardening on the Hoskins oil palm scheme, in R.M. Bourke and V. Kesavan (eds), Proceedings of the Second Papua New Guinea Food Crops Conference, pp. 168-175. Port Moresby: Department of Primary Industry.

Bourke, R.M. (2000) An overview of food security in PNG, in R.M. Bourke, M.G. Allen and J.G. Salisbury (eds), Food Security for Papua New Guinea, pp. 5-14. Proceedings of the Papua New Guinea Food and Nutrition 2000 conference, PNG University of Technology, Lae. Canberra: Australian Centre for International Agricultural Research.

Bourke, R.M. (2001) Intensification of agricultural systems in Papua New Guinea, Asia Pacific Viewpoint 42(2-3): 219-236.

Bourke, R.M., J. Gibson, A. Quartermain, K. Barclay, B. Allen and J. Kennedy (2009) Food production, consumption and imports, in R.M. Bourke and T. Harwood (eds), Food and agriculture in Papua New Guinea, pp. 129-192. Canberra: ANU Press.

Curry, G.N. and G. Koczberski (2009) Finding common ground: Relational concepts of land tenure and economy in the oil palm frontier of Papua New Guinea, The Geographical Journal 175(2): 98-111.

Curry, G.N., G. Koczberski, J. Lummani, S. Ryan and V. Bue (2012) Earning a living in Papua New Guinea: From subsistence to a cash economy, in M. Robertson (ed.), Schooling for sustainable development. A focus on Australia, New Zealand and the Oceanic Region, pp. 159-184. Dordrecht: Springer.

Curry, G.N., G. Koczberski, E. Omuru, J. Duigu, C. Yala and B. Imbun (2007) Social assessment of the smallholder agriculture development project. Report prepared for the World Bank.

Dewhurst, R. (2007) Where's the balance? Oil palm, subsistence production and gender relations in smallholder households of Papua New Guinea. Honours Dissertation. Nottingham: University of Nottingham.

Evans, H. and P. Ngau (1991) Rural-urban relations, household income diversification and agricultural productivity, Development and Change 22: 519-545.

Gibson, J. (2000) The economic and nutritional importance of household food production in $P N G$, in R. M. Bourke, M.G. Allen and J.G. Salisbury (eds), Food Security for Papua New Guinea, pp. 37-44. Proceedings of the Papua New Guinea Food and Nutrition 2000 Conference, PNG University of Technology, Lae. Canberra: Australian Centre for International Agricultural Research.

Hulme, D. (1984) Land settlement schemes and rural development in Papua New Guinea, Unpublished Ph.D thesis. Townsville: James Cook University.

Keig, G. (2001) Rural population growth in Papua New Guinea between 1980 and 1990, Asia Pacific Viewpoint 46(2): 255-268. 
Koczberski, G. and G.N. Curry (2005) Making a living: Land pressures and changing livelihood strategies among oil palm settlers in Papua New Guinea, Agricultural Systems 85: 325-339.

Koczberski, G., G.N. Curry and J. Anjen (2012) Changing land tenure and informal land markets in the oil palm frontier regions of Papua New Guinea: The challenge for land reform, Australian Geographer 43(2): 181- 196.

Koczberski, G., G.N. Curry and K. Gibson (2001) Improving productivity of the smallholder oil palm sector in Papua New Guinea: A socio-economic study of the Hoskins and Popondetta schemes. Department of Human Geography, Research School of Pacific and Asian Studies. Canberra: Australian National University.

Koczberski, G., G.N. Curry and B. Imbun (2009) Property rights for social inclusion: Migrant strategies for securing land and livelihoods in Papua New Guinea, Asia Pacific Viewpoint 50(1): 29-42.

Landell Mills Ltd (1991) Smallholder oil palm productivity study. Konedobu: Department of Agriculture and Livestock, Papua New Guinea.

McGregor, A. and R.M. Bourke (2009) The broader economy, in R.M. Bourke and T. Harwood (eds), Food and agriculture in Papua New Guinea, pp. 271-282. Canberra: ANU E Press.

Ryan, S. (2009) Maximising income: Livelihood change and Risk management for oil palm settlers in Papua New Guinea (a case study through the local markets). Honours Dissertation. Perth: Curtin University of Technology.

Storey, D. (2006) Urbanisation in the Pacific, State, Society and Governance in Melanesia Project, Research Paper. Canberra: Australian National University. 